\title{
Geotechnical investigation of road pavement failure along arigidi / oke - agbe akoko, southwestern, Nigeria
}

\author{
Thompson Henry Tolulope Ogunribido ${ }^{1 *}$, Tunde Ezekiel Fadairo ${ }^{1}$ \\ ${ }^{1}$ Department of Earth Sciences, Adekunle Ajasin University, Akungba-Akoko, Ondo State, Nigeria \\ *Corresponding author_E-mail: ogunribido_henry@yahoo.com
}

\begin{abstract}
Twenty soil samples collected from the failed portions in the study area were air dried for two weeks before analyses. Each soil samples were subjected to eight engineering tests which include: natural moisture content, atterberg limit, specific gravity, compaction, unconfined compressive strength, California bearing ratio, grain size and hydrometer analysis. Results showed that the natural moisture content ranged from $17.7 \%$ to $37.8 \%$, liquid limit from $48.5 \%$ to $62.4 \%$, plastic limit from $18.3 \%$ to $26.8 \%$, plasticity index from $25.7 \%$ to $37.7 \%$, shrinkage limit from 5.8\%-12.5\%, optimum moisture content from $14.2 \%$ to $32.4 \%$, maximum dry density from $1301 \mathrm{Kg} / \mathrm{rn} 3$ to $2002 \mathrm{Kg} / \mathrm{rn} 3$. Soaked California bearing ratio ranged from $5 \%$ to $17 \%$, unsoaked from $15 \%$ to $38 \%$, specific gravity from 2.5 to 2.68 , unconfined compressive strength $\mathrm{r}$ from $112.8 \mathrm{Kpa}$ to $259.7 \mathrm{Kpa}$, shear strength from $56.4 \mathrm{Kpa}$ to $129.9 \mathrm{Kpa}$ and hydrometer analysis from $48.5 \%$ to $72.1 \%$. Based on the Federal Government specifications for pavement construction, for the soil to be suitable, stabilization with bitumen, Portland cement, lime, coal fly ash, and saw dust should be done. Road pavement failure along Arigidi - Oke Agbe road was due to poor engineering geological condition of the sub-grade soils and poor drainage systems.
\end{abstract}

Keywords: Road Pavement; Geotechnical; Potholes; Compaction; Consistency Limits.

\section{Introduction}

A pavement may be defined as the structural material placed above a subgrade layer (Woods and Adcox, 2002). Ability of pavement to support loads depends primarily upon the magnitude of the load, how often it is applied, the supporting power of the soil underneath, and the type of the pavement structure. In asphaltic pavement, it is typically a multi-layered system comprising the subgrade, sub-base and base course and surfacing. Its principal function is to provide friction for the vehicles, also to receive load from the traffic and transmit to the pavement and then become defective, when it can no longer preform these functions during its design life. Modern flexible pavements contain sand and gravel or crushed stone compacted with a binder of bituminous material, such as asphalt, tar, or asphaltic oil. Flexible pavement has enough plasticity to absorb shock. Rigid pavements are made of concrete, composed of coarse and fine aggregate and Portland cement, and usually reinforced with steel rod or mesh. Rocks and soil are materials widely used for construction purposes. The qualities of these construction materials are essential in their choice for various civil works. These qualities are evaluated by the geotechnical test of the soil materials. Road failures could be defined as a discontinuity in road network resulting in cracks, potholes, bulges, patching and depressions (Meshida, 2006). A road network is supposed to be a continuous stretch of asphalt lay for a smooth ride or drive but visible cracks, potholes, bulges and depressions may punctuate such smooth ride and this punctuation in smooth ride is generally regarded as road failure. However, majority of expressway failure in the tropics can be traced to geotechnical factors (Gidigasu, 1976; Meshida, 1987; Madebors, 1983; Adeyemi, 1994). These authors observe that expressway failure often occur when the pavement is built on Saprolite instead of lateritic profiles. Sequel to the loss of lives and properties as a result of expressway failure, it is pertinent that the geotechnical investigation of the failed sections of the road should be carried out. This will help to ascertain factors responsible for failure and this will enhance future designing and construction of durable roads. Researchers in the past on geotechnical properties of lateritic soils include Mesida, 1985, Jegede, 1994, Ola, 1980, Adeyemi and Oyeyemi, 2000, Adeyemi, 2003 Ola, 1983, Aguda, 1982, Ogunsanwo, 2000, Ogunribido, 2012a, b and c.

\section{Location, physiography and geology of the study area}

This research was carried out along Arigidi/Oke -AgbeAkoko road in Ondo state southwestern Nigeria. The topography is characterized with varying lithology ranging from conspicuous highlands of older granites to fairly undulating terrain of ironstone (Figure 1). The drainage pattern of the study area is the combination of both trellis and dendritic. They show the resistance of the underlying crystalline basement rock. Stream and rivers developed along major joint directions and foliation trend with straight courses. These factors were responsible for the trellis and dendritic patterns in the study area. 


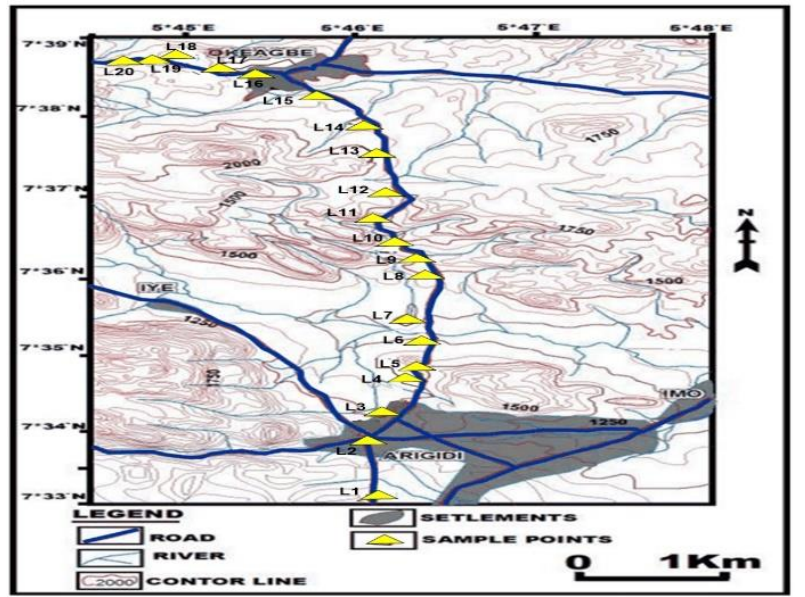

Fig. 1: Topographical Map of the Study Area. Source: Department of Earth Sciences, A.A.U.A.

The vegetation comprises of tall trees with buttress roots, evergreen and broad leaves and numerous species of trees like Mahogany, Iroko, African walnut which encourages timber business. The study area belongs to the Basement Complex of southwestern Nigeria (Figure 2). It is a heterogeneous assemblage including migmatite, orthogneisses, paragneisses and a series of basic and ultrabasic metamorphosed rocks (Rahaman, 1976; Rahaman, 1988, Rahman and Ocan, 1988). Major rock types are Biotite gneiss, pegmatite, granite, granite gneiss, grey gneiss, Pelitic gneiss, quartzite, charnockitic gneiss and charnockite.

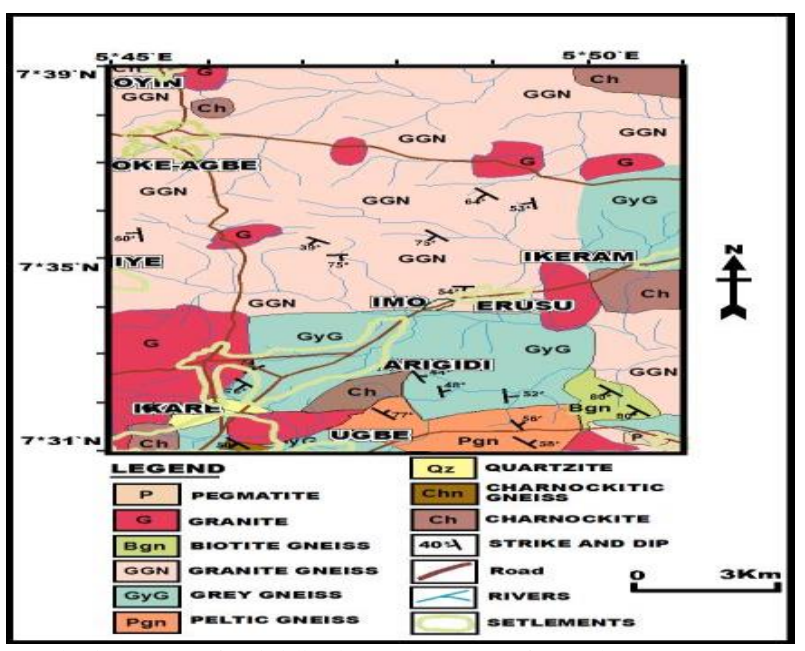

Fig. 2: Geological Map of Arigidi/Oke-Agbe Area (after Rahaman and Ocan, 1988).

\section{Materials and method}

Twenty soil samples were collected at the depth of 1.5 meters and were taking to geological laboratory of Adekunle Ajasin University, Akungba Akoko and were air dried for 2 weeks before analyses. Soil samples were collected from the failed portion of the road in the study area. The samples were immediately stored in sample bags to protect it from loss of moisture. Outcrops were also mapped in order to know the origin of the soil in the area. Tests carried out on each sample include natural moisture content, grain size analysis, consistency limit test, specific gravity, California bearing ratio, compaction test, hydrometer and unconfined compressive strength. All the laboratory tests conducted were in conformity with the procedures specified in the British Standard Institute, BSI 1377, (1975), BSI1 1377, (1990).

\section{Results and discussion}

The results of the index properties of soil are presented in Table 1, grain size and hydrometer tests in Table 2, and strength properties in Table 3.

Table 1: Summary of the Index Properties of Soil in the Study Area

\begin{tabular}{|c|c|c|c|c|c|c|}
\hline Locatoin & $\mathrm{MC}(\%)$ & LL (\%) & PL (\%) & PI (\%) & LS (\%) & Gs \\
\hline L1 & 37.8 & 62.4 & 24.7 & 37.70 & 5.8 & 2.1513 \\
\hline L2 & 33.4 & 46.2 & 22.6 & 23.60 & 10.6 & 2.566 \\
\hline L3 & 21.7 & 55.6 & 22.8 & 32.70 & 12.5 & 2.683 \\
\hline $\mathrm{L} 4$ & 25.3 & 55.1 & 24.3 & 30.80 & 10.1 & 2.663 \\
\hline L5 & 24.7 & 57.2 & 24.3 & 32.90 & 11.0 & 2.629 \\
\hline L6 & 18.1 & 54.5 & 21.8 & 32,70 & 10.1 & 2.644 \\
\hline L7 & 18.3 & 54.1 & 22.7 & 31.40 & 11.5 & 2.629 \\
\hline L8 & 22.3 & 48.5 & 18.5 & 30.00 & 11.5 & 2.640 \\
\hline L9 & 20.5 & 50.2 & 26.8 & 23.40 & 12.0 & 2.681 \\
\hline L10 & 20.7 & 49.9 & 24.2 & 25.7 & 10.6 & 2.670 \\
\hline L11 & 18.6 & 50.1 & 18.8 & 31.30 & 9.3 & 2.511 \\
\hline
\end{tabular}




\begin{tabular}{|c|c|c|c|c|c|c|}
\hline L12 & 19.8 & 49.8 & 18.3 & 31.50 & 9.1 & 2.565 \\
\hline L13 & 22.7 & 53.5 & 25.3 & 28.20 & 11.0 & 2.658 \\
\hline L14 & 21.8 & 53.9 & 25.7 & 28.20 & 9.1 & 2.610 \\
\hline L15 & 18.2 & 54.4 & 23.8 & 30.60 & 6.8 & 2.628 \\
\hline L16 & 18.9 & 55.0 & 22.9 & 32.10 & 12.0 & 2.641 \\
\hline L17 & 25.4 & 55.9 & 18.7 & 37.20 & 11.5 & 2.623 \\
\hline L18 & 17.7 & 54.6 & 22.1 & 32.50 & 12.5 & 2.639 \\
\hline L19 & 17.7 & 50.8 & 22.1 & 28.70 & 9.1 & 2.636 \\
\hline L20 & 22.2 & 54.2 & 21.6 & 32.60 & 11.5 & 2.661 \\
\hline Mean & 22.29 & 58.3 & 22.6 & 30.69 & 10.38 & 2.624 \\
\hline
\end{tabular}

\begin{tabular}{|c|c|c|c|c|c|c|}
\hline Location & Gravel (\%) & Sand $(\%)$ & Silt (\%) & Clay (\%) & Fines $(\%)$ & Hydrometer (\%) \\
\hline L1 & 1.2 & 20.0 & 14.0 & 65.9 & 80.0 & 48.5 \\
\hline $\mathrm{L} 2$ & 1.4 & 71.8 & 11.9 & 15.0 & 26.8 & 64.6 \\
\hline L3 & 1.3 & 43.6 & 14.6 & 40.5 & 55.1 & 48.9 \\
\hline $\mathrm{L} 4$ & 12.4 & 56.8 & 12.3 & 18.5 & 30.7 & 62.8 \\
\hline L5 & 2.3 & 60.2 & 14.3 & 23.4 & 37.5 & 54.5 \\
\hline L6 & 1.2 & 68.6 & 12.6 & 17.6 & 30.3 & 60.3 \\
\hline L7 & 1.1 & 37.9 & 16.1 & 44.9 & 61.0 & 53.0 \\
\hline L8 & 5.4 & 73.4 & 11.9 & 9.3 & 21.2 & 72.1 \\
\hline L9 & 1.0 & 43.5 & 17.4 & 38.0 & 55.4 & 50.0 \\
\hline L10 & 1.0 & 38.7 & 16.7 & 43.5 & 60.3 & 51.2 \\
\hline L11 & 1.2 & 19.9 & 14.1 & 65.9 & 80.1 & 48.5 \\
\hline L12 & 1.4 & 71.6 & 12.1 & 15.0 & 27.0 & 64.6 \\
\hline L13 & 1.3 & 42.1 & 16.1 & 40.5 & 56.6 & 48.9 \\
\hline L14 & 1.2 & 55.9 & 13.4 & 18.5 & 55.9 & 62.8 \\
\hline L15 & 2.2 & 57.6 & 17.0 & 23.2 & 57.6 & 54.5 \\
\hline L16 & 1.2 & 70.3 & 10.9 & 17.6 & 28.5 & 60.3 \\
\hline L17 & 1.1 & 37.9 & 16.1 & 44.9 & 61.0 & 53.0 \\
\hline L18 & 5.6 & 76.6 & 8.5 & 9.3 & 17.7 & 72.1 \\
\hline L19 & 1.1 & 44.9 & 16.0 & 38.0 & 54.1 & 50.0 \\
\hline L20 & 1.1 & 39.6 & 15.8 & 43.5 & 59.4 & 51.2 \\
\hline Mean & 2.3 & 51.5 & 14.9 & 31.65 & 47.81 & 56.59 \\
\hline
\end{tabular}

\begin{tabular}{|c|c|c|c|c|c|c|}
\hline Location & $\mathrm{OMC}(\%)$ & MDD (\%) & Unsoaked CBR (\%) & Soaked CBR (\%) & UCS $(\mathrm{kPa})$ & Shearing strength $(\mathrm{kPa})$ \\
\hline L1 & 32.4 & 1336 & 15 & 5 & 217.5 & 108.7 \\
\hline L2 & 16.2 & 1897 & 32 & 12 & 131.3 & 65.7 \\
\hline L3 & 27.3 & 1511 & 17 & 6 & 194.2 & 97.1 \\
\hline L4 & 21.1 & 1721 & 33 & 13 & 113.2 & 56.6 \\
\hline L5 & 27.3 & 1511 & 28 & 10 & 145.9 & 73.0 \\
\hline L6 & 21.8 & 1704 & 34 & 13 & 112.8 & 56.4 \\
\hline L7 & 27.3 & 1511 & 31 & 13 & 142.0 & 71.0 \\
\hline L8 & 13.2 & 2002 & 36 & 15 & 160.7 & 80.4 \\
\hline L9 & 28.3 & 1476 & 28 & 12 & 180.3 & 90.1 \\
\hline L10 & 27.3 & 1511 & 19 & 8 & 170.2 & 85.1 \\
\hline L11 & 33.4 & 1401 & 23 & 5 & 259.6 & 129.8 \\
\hline L12 & 17.2 & 1861 & 19 & 7 & 229.2 & 114.6 \\
\hline L13 & 28.3 & 1476 & 36 & 15 & 217.6 & 108.8 \\
\hline L14 & 20.2 & 1756 & 28 & 12 & 131.4 & 65.7 \\
\hline L15 & 19.2 & 1791 & 25 & 11 & 142.1 & 71.0 \\
\hline L16 & 18.2 & 1826 & 23 & 4 & 160.6 & 80.3 \\
\hline L17 & 26.3 & 1546 & 19 & 6 & 180.2 & 90.1 \\
\hline L18 & 14.2 & 1967 & 35 & 13 & 170.2 & 85.1 \\
\hline L19 & 24.3 & 1616 & 38 & 17 & 259.7 & 129.9 \\
\hline L20 & 25.3 & 1581 & 32 & 9 & 229.3 & 114.7 \\
\hline Mean & 23.44 & 1645.05 & 27.55 & 10.3 & 177.4 & 88.705 \\
\hline
\end{tabular}

\subsection{Natural moisture content}

The natural moisture content of the study area ranged from 17.7\% to 37.8\% (Table 1). Samples L18 and L19 has the lowest value of $17.7 \%$ while sample L1 has the highest value of $37.8 \%$, the mean was $22.29 \%$. Samples collected at location L1 to L20 have high moisture content in their natural state. An increase in soil moisture above the optimum implies weakness in the soils that leads to swelling which cause damage to the pavement and when losing the water, there will be shrinkage. The reason for high moisture content in some of the soil samples is influenced by the season, clay content and drainage condition of the environment, because these factors do influence in-situ moisture (Arumala and Akpokodje, 1987). The strength and cohesion capacity of the soil is averagely low. It can be considered for simple engineering purposes. Excessive moisture content is responsible for swelling of soil and moisture variation is generally determined by intensity of rain, depth of collection of sample and texture of the soil (Jegede, 1994 and 2004).

\subsection{Liquid limit}

The values of the liquid limit ranged from 46.2 to $62.4 \%$. From the result obtained it was observed that the sample collected at location L1 has the highest liquid limit $62.4 \%$ while the sample obtained in location L2 at the has the lowest liquid limit $46.2 \%$, the average mean value 
of the liquid limit obtained from the study area was 58.3\%. According to (Arumala and Akpokodje, 1987), the standard set by the Federal Government for pavement design is that the liquid limit must not be greater than 30, but all the samples in the study area exceeded the $30 \%$ as specified by the Nigerian Government (Table 4).

\subsection{Plastic limit}

In this study, plastic limit ranged from $18.3 \%$ to $26.8 \%$. It was observed that samples at location L18 and L19 crumbled before $3 \mathrm{~mm}$; this is due to the non-plastic nature of the soil samples at these locations. Sample obtained at L9 has the highest plastic limit (26.8\%) while the sample collected at location L12 has the lowest plastic limit (18.3\%), the average mean value of the plastic limit of the study area was $22.6 \%$ (Table 1).

\subsection{Plasticity index}

Location L1 has the highest plasticity index of 37.7 while the sample in location L9 has the lowest plasticity index of $23.4 \%$. The plasticity index obtained ranged from $23.4 \%$ to $37.7 \%$, with mean as $30.9 \%$. Generally, soil having high value of liquid limit and plastic limits are considered poor as sub-grade materials, however a large plasticity index, such as $37.7 \%$ shows that considerable volume of water can be added before the soils becomes liquid. The larger the plasticity index of soil, the greater the engineering problems associated with using the soil as an engineering material as the case in the study area.

\subsection{Linear shrinkage}

The linear shrinkage values ranged from $5.8 \%$ to $12.5 \%$., with a mean value of $10.38 \%$. Samples collected in the study area are good subgrade materials except in those in locations L1, L2, L14, L15, L16 and L20 since they have linear shrinkage values greater than 8.0 and are likely to be subjected to swelling and shrinkage during alternate dry and wet season of the humid tropical climate condition of Southwestern Nigeria.

\subsection{Specific gravity}

For normal inorganic soil the specific gravity is usually between 2.51 and 2.68 ; while clayey soils tend toward 2.8. The specific gravity ranged between 2.51 to 2.68. Sample collected at location L11 have the lowest value of 2.51 while samples from locations L3 and L9 has the highest value of 2.68. High values may be due to the presence of heavy minerals in the parent basement rocks. Specific gravity of soils is an important parameter in soil engineering design.

\subsection{Grain size analysis}

Sample at location 1 and location 11 has the lowest percentage passing in the 0.075 micrometer sieve size $(0.075 \mu \mathrm{m})$ which is silty clay, samples at location 16 and location 6 percentage passing of $(0.075 \mu \mathrm{m})$ in the same sieve has the highest value. The value of the particle size analysis ranged between 456.62 to 484.03 with location 3 having the lowest and location 8 having the highest value, and an average mean value of 470.06 (Table 2). Based on the Unified Soil Classification System (USCS), soils with number of fines (silt and clay) ranging between 0 and 5\% are generally described as well-graded, while those in the range of 5-15\% are well-graded clayey sand or gravel. Soils in the range $15-35 \%$ are described as very clayey. On this basis, all the soil samples are clayey. Rowe et al (1995), described materials with high clay content or a high silt and clay content as the soils that will display low permeability for a sanitary landfill.

\subsection{Hydrometer analysis}

The hydrolysis values ranged from $48.5 \%$ to $72.1 \%$ (Table 2). Sample collected at location L1 and L11 have the lowest value of $48.5 \%$ respectively while the sample collected at location L8 and L18 has the highest value of $72.1 \%$ indicating that the sample in L5 and L13 has more pore spaces for water intake.

\subsection{Compaction test}

The soils were compacted using standard proctor AASHTO level of compaction to determine the compaction level for the samples. From the Table 3, the maximum density of the soil samples (MDD) ranged from $1301 \mathrm{Kg} / \mathrm{rn}^{3}$ to $2002 \mathrm{Kg} / \mathrm{rn}^{3}$ with optimum moisture content (OMC) ranged from $14.2 \%$ to $32.4 \%$. The MDD of all the soil samples have values less than the recommended value of $2165 \mathrm{Kg} / \mathrm{rn}^{3} \mathrm{for}$ Nigeria soils. Therefore, the soils can be regarded as poor sub-grade materials. Generally, soil with higher dry density value and low optimum moisture content are best soil for road construction.

\subsection{California bearing ratio (CBR)}

Results of the soaked soil sample yielded different results with the value ranging from 5\% to $17 \%$ and the unsoaked ranges from $15 \%$ to $38 \%$. Soil samples at L19 have the highest value and L1 have the lowest value for unsoaked samples, while for soaked sample, it was observed that L19 has the highest value and L1 has the lowest value. These results show that the subsoil used in the road construction are very weak. From Table 4, The Federal Government of Nigeria standard specification for road design stipulate that an unsoaked value greater than $80 \%$ is the accepted value for road course material. (Arumala and Akpokodje, 1987)

\subsection{Unconfined compressive strength}

The Unconfined compressive strength values ranged from $112.8 \mathrm{Kpa}$ to $259.7 \mathrm{Kpa}$. Sample at location L6 have the lowest UCS value with shear strength of 56.4Kpa while the sample in location L19 has the highest UCS value of with the shear strength of $129.9 \mathrm{kpa}$. 
Table 4: Road Standard Specification for Pavement Design by the Federal Government

\begin{tabular}{ll}
\hline Percentage fines $(\%)$ & Not greater than 15 \\
\hline Liquid limits $(\%)$ & Not greater than 30 \\
Plasticity index $(\%)$ & Not greater than 12 \\
Linear shrinkage $(\%)$ & Not greater than 8 \\
CBR (soaked) $(\%)$ & Unsoaked must be greater than 80 \\
CBR (unsoaked) $(\%)$ & Soaked must be greater than 30 \\
\hline
\end{tabular}

Source: Federal Government on Pavement Design (2015).

\section{Conclusion}

From the study, it was discovered that poor geotechnical properties of the sub-base and base course were responsible for the failure of the road pavement. The liquid limit and the plasticity index do not conform to the standard specification. From the engineering geological investigation carried out in this study, inadequate and poor drainage facilities, improper road cut, non-provision of pavement shoulders have caused the failure of some portion of the road which has led to waste of resources, and most times goods that are been transported along the stretch of the road is wasted.

It is important that the materials that conform to the specification are used in the construction of road pavement. In the study area soil samples has poor geotechnical properties, for this material to be suitable there is need for stabilization with bitumen, Portland cement, lime, coal fly ash, saw dust ash among others. Good drainage network must be provided to prevent further failure of the road, this will prevent ingress of water into the road pavement, thus reducing the risk of decreasing the CBR value on which the road pavement was designed.

\section{References}

[1] Woods, W.R and Adcox, J.W. (2002): A General Classification of Pavement System Failure with emphasis on a method for selecting repair process, Journal of Construction Education, 7(1):58-62.

[2] Meshida E.A (2006): Highway failure over talc-tremolite schist terrain: a case study of Ife to Ilesha highway, south-western Nigeria. Bulleting of Engineering Geology and the Environment. Vol. 65, pp. 457-461. https://doi.org/10.1007/s10064-005-0037-7.

[3] Gidigasu, M.D, (1976): Laterite soil engineering pedo-genesis and engineering principles,” Amsterdam Elsevier Scientific, New York, pp. 554.

[4] Meshida, E.A. (1987): The relationship between the geology and the laterite engineering soils in the Northern Environs of Akure Nigeria, Bulletin of the Association of Engineering Geology. Paris. Pp.65-69. https://doi.org/10.1007/BF02590478.

[5] Madebor, A.O. (1983): Pavement Design, Guidelines and Practice for different Geological areas of Nigeria. Pp. 290 - 297.

[6] Adeyemi, G. O. (1994): Clay mineralogy, major elements geochemistry and strength characteristics of three highway subgrade soils in South-western Nigeria. Bulletin of the international Association of Engineering Geology, No 50, 5-8 https://doi.org/10.1007/BF02594951.

[7] Meshida, E.A (1985): Engineering properties of lateritic soils of some part of SW Nigeria, unpublished PhD Thesis, University of Ife, Ile-Ife, Nigeria

[8] Jegede, G.A (1994): Engineering Geological properties of the superficial deposits overlying the Carboniferous limestone syncline in Co. Cork Ireland, Nigerian Journal of Science, Pp. 154-158.

[9] Ola. S.A, (1980): Geotechnical properties and behaviour of some stabilized Nigerian lateritic soil. Quarterly Journal of Engineering Geology London. Vol.11, Pp. 148-160 https://doi.org/10.1144/GSL.QJEG.1978.011.02.04.

[10] Adeyemi, G.O and Oyeyemi, F, (2000): Geotechnical basis for failure of sections of the Lagos-Ibadan expressway, S.W Nigeria. Bulletin of the Engineering Geology and Environment. https://doi.org/10.1007/s100649900016.

[11] Adeyemi G.O, (2003): The influence of topography on some engineering and geological characteristics of two sandstones derived lateritic soils from Ishara, S.W Nigeria. Jour.Appl. Science and technology, vol. 3, pp.1-6. https://doi.org/10.4314/jaset.v3i1.38249.

[12] Ola. S.A, (1983). Geological properties and behaviour of some Nigerian lateritic soil. In Ola, S.A. (ed) Tropical soil of Nigeria in engineering practice.

[13] Aguda, B.O, (1982): Causes of Highway pavement failures in Ibadan. Nigeria journal of technology. vol. 3, pp. 52-54.

[14] Ogunsanwo, O. (2000): Highway geotechnical properties of five lateritic soils in SW. Nig. Unpub. B.sc thesis, dept. of civil engineering, O.A.U, IleIfe.

[15] Ogunribido, T.H.T (2012): Effects of rock flour on some Engineering properties of lateritic Soil, International Journal of Pure and Applied science and Technology, Vol.10, no. 1, pp. $10-16$.

[16] Ogunribido, T.H.T (2012): Geotechnical properties of saw dust ash stabilized SW, Nigeria Lateritic soils, Scientific Journal of Environmental research, Engineering and Management, No. 2(60), pp. 29 - 33. https://doi.org/10.5755/j01.erem.60.2.986.

[17] Ogunribido, T.H.T (2012): Potentials of Sugar cane straw ash for lateritic soil Stabilization in Road Construction, International Journal of Science and Emerging Technologies, Vol. 3, no. 5, pp. $102-106$.

[18] Rahaman, M. A, (1976): A review of the Precambrian rocks of south-western Nigeria, G.N. S. Kogbe (editor) Pp. 41-55.

[19] Rahaman M. A. (1988) - Recent advances in the study of the basement complex of Nigeria, symposium on the geology of the basement complex of Nigeria, Obafemi Awolowo University, Ile - Ife, Nigeria

[20] Rahaman, M.A., and Ocan, O.O., (1988): On relationship in the Precambrian migmatite gneisses of Nigeria. Journal of. Mining and Geology, Vol. $15,(1)(a b s)$

[21] BSI 1377, (1975): Methods of Test for civil Engineering Purposes, British Standard Institution, London.

[22] British Standards Institute-BSI 1377 (1990): Methods of Tests for soils for civil engineering purposes.

[23] Arumala, J.O and Akpokodje, E.G (1987): Soil Properties and Pavement Performance in Niger Delta, Quarterly Journal of Engineering Geology.Vol.20, Pp. 287-289. https://doi.org/10.1144/GSL.QJEG.1987.020.04.05.

[24] Jegede, G. A (2004): Highway pavement Failure induced by properties along a section of F209 Okitipupa-Igbokoda Highway South-western, Nigeria Ife Journal of. Science, 6(10):41-44. https://doi.org/10.4314/ijs.v6i1.32121.

[25] Rowe, R. K., Quigley, R. M. and Booker, J.R. (1995): Clayey barrier systems for waste disposal facilities, E \& FN Spon, London. https://doi.org/10.4324/9780203302064.

[26] Federal Government on Pavement Designed (2015): Showing the soil classification as it relates with Plasticity Index. 